\title{
LEARNING METHODS AND THEIR EFFICIENCY IN AGRICULTURAL ORGANISATIONS IN THE CZECH REPUBLIC
}

\author{
Hana Urbancovál, Adéla Fajč́́kovál, Václav Kala ${ }^{1}$ \\ ${ }^{1}$ Department of Management, Faculty of Economics and Management, Czech University of Life Sciences Prague, \\ Kamýcká 129, 16521 Prague 6, Czech Republic
}

\begin{abstract}
URBANCOVÁ HANA, FAJČíKOVÁ ADÉLA, KALA VÁCLAV. 2018. Learning Methods and their Efficiency in Agricultural Organisations in the Czech Republic. Acta Universitatis Agriculturae et Silviculturae Mendelianae Brunensis, 66(4): 1035-1041.

Education and employee development are among the most important areas where employers can look for new efficient ways and methods for gaining a competitive advantage in the form of employee knowledge. Systematic education increases the potential of the workforce which has a positive impact on all organisation processes in all sectors, including agriculture. The objective of this paper is to evaluate the deployment of educational methods in Czech agricultural organisations and to assess their efficiency within the educational process. The data was obtained through a quantitative survey, specifically a questionnaire, among selected agricultural organisations operating in the Czech Republic $(\mathrm{n}=70)$. The evaluation involved independence tests (the $\chi^{2}$ test) and multi-dimensional statistics (factor analysis). The results showed that most of the surveyed agricultural organisations have implemented an educational process in order to develop competencies among their staff. Among the surveyed organisations, the results have identified 4 organisational approaches to the use of educational methods $(0.404-0.860)$ and two ways how to evaluate their efficiency in the educational process $(0.519-0.889)$. Testing has proven a correlation between whether an agricultural organisation develops education systematically, plans educational activities for a pre-defined period and evaluates the efficiency of educational activities using selected identification variables.
\end{abstract}

Keywords: agriculture, educational program, knowledge sharing, learning methods, the Czech Republic

\section{INTRODUCTION}

Employee education and development are important aspects that affect the ability of an organisation to achieve competitive advantage by influencing employee behaviour and performance (Hanaysha and Tahir, 2016). According to Kragulj (2016), organisational learning leads to organisational changes and uses and builds new knowledge; it's also widely accepted that knowledgeable employees are the only permanent competitive advantage of any organisation (Liu, 2017). The changes caused by today's global environment stimulate a need to share experience and plan systematic education in all organisations (Araújo and Pestana, 2017; Razak et al., 2016). Organisational learning is becoming even more important for strategic renewal; organisations must be efficient and adapt to various changes (Diaz-Fernandez et al., 2017) not just on the labour market. The shift towards more standardised agricultural information and knowledge is mainly caused by increased capital requirements, extended scope, specialisation and mechanisation (Seuneke et al., 2013; Šümane et al., 2017). Šümane et al. (2017) also point out that the transformation towards a more sustainable agriculture requires a new knowledge base with a new content and form of knowledge, including new learning processes.

Saks and Haccoun (2010) divide learning methods depending on where they take place (on the job or off the job methods). Vodák and Kucharčíková (2011) 
add that on the job education is more suitable for manual workers and can include job rotation, coaching, mentoring and work on projects. On the other hand off the job methods are intended primarily for managers and specialists and include lectures, self-education, assessment centre, workshop or experiential learning. According to Dávideková et al. (2017) the most commonly used educational methods in organisations are self-learning, coaching, mentoring, job rotation, e-learning and lectures. Pulakos et al. (2015) claim, that truly effective methods that yield positive change in employee behaviour are based on experiential learning right at the workplace. Rao and Kumar (2017a) also highlight the need to monitor and evaluate the impact of educational programs on the efficiency and productivity of employees. The techniques that are used in practice can be summarized as measuring performance before, during and after the implementation of educational program, evaluation of meeting the objectives of education, assessment based on the reaction of superiors and the participants themselves or observation at work (Aswathappa, 2005; Rao and Kumar 2017a; Rao and Kumar 2017b).

But it's entirely up to the decision of the management of any individual organisation whether it will focus adequately on education, which educational methods it is going to use for employees and whether it will evaluate the efficiency of these methods based on participant feedback and the results of the educational process.

The objective of this paper is therefore to evaluate the deployment of educational methods in Czech agricultural organisations and to assess the efficiency of the educational process. A partial objective is also to determine if there is any correlation between the educational process and selected identification variables characterising the organisation. The paper is structured as follows: the first chapter, Materials and Methods, provides a detailed description of the used theoretical methods of research that were applied in the collection of primary data. Evaluation of the results and their comparison with the results of the research of education in the primary sector is contained in the Results and Discussion chapter. Summary recommendations are provided in the Conclusion.

\section{MATERIALS AND METHODS}

The paper was primarily based on an analysis of secondary and primary sources, a synthesis of obtained knowledge, induction, deduction and comparison. The used secondary sources are scholarly papers from the Web of Knowledge database that deal with education and the educational process in all aspects of commercial activity including agriculture. Primary data was obtained through quantitative research, specifically an online data collecting questionnaire. The research was carried out in selected agricultural organisations in the Czech Republic.

The total number of agricultural organisations in the sample is $\mathrm{n}=70$. The organisations were randomly selected from all regions of the Czech Republic and the results can be generalised only for this selected sample. An electronic questionnaire consisted of ten closed and semi-closed questions with multiple answers. The questions were based on theoretical background dealing with the issue and related to educational process in organisations.

The person responsible for completing the questionnaire in each organisation was a middle or high-level manager; in the case of smaller organisations, it was the owner.

For ethical reasons, the questionnaire respected the anonymity of respondents. The structure of agricultural organisations that took part in the survey was as follows:

- Sector: private sector $70.0 \%$, public sector $11.4 \%$, state-owned $18.6 \%$.

- Target market: local 4.3\%, regional 31.4\%, national $38.6 \%$, international $25.7 \%$.

- Part of a larger group of organisations: $27.1 \%$ are part of an international organisation and $72.9 \%$ are not.

- Size of the organisation: 1-49 employees 45.7\%, 50-249 employees 32.9\%, 250 and more employees $21.4 \%$.

- HR department existence: $68.6 \%$ of the surveyed organisations have an HR department; $31.4 \%$ do not have an HR department.

The evaluation of the results employed several tools used in descriptive statistics, namely absolute and relative frequency, as well as an independence test. Specifically, the $\chi^{2}$ test was used; if the calculated $\mathrm{p}$-value was below the significance threshold $\alpha=0.05$, the null hypothesis was rejected. Strength of the correlation was then determined using Cramer's V and interpreted in accordance with the categories described by De Vaus (2014). The paper tested the following summary statistical null hypotheses concerning the educational process in surveyed agricultural organisations:

- H01: There is no statistical correlation between whether agricultural organisations are planning and implementing educational activities and selected identification variables characterising the organisation.

- H02: There is no statistical correlation between whether agricultural organisations are evaluating the efficiency of education and selected identification variables characterising the organisation.

For every null hypothesis, we also tested for correlation between the educational process and sector of activity, target market, whether the organisation is part of a larger group of organisations, size of the organisation and the existence of an HR department. 
From multi-dimensional statistical methods, we employed factor analysis. The calculation and data interpretation methods were based on the work of Hebák et al. (2014), Anderson (2009) and Pecáková (2011). The factors explain the variability and correlations between the selected variables. In the case of factor analysis, the approach is more heuristic, requiring an understanding of the issue as well as considerable knowledge of and experience with the selected data analysis method. That's why some statisticians reject this method as inexact, subjective and unconvincing; on the other hand, researchers active in social sciences, such as sociologists, use factor analysis often and consider it highly trustworthy (Hendl, 2012). The method is also popular and often used in human resources research (Anderson, 2009), which is why it was employed in this survey for verification purposes. We employed the Varimax method of factor analysis and used the Kaiser-Guttman rule to select significant factors (i.e. those with variance higher than 1). In the results of the factor analysis, significant values were those with a value exceeding 0.3 (Anderson, 2009) which are considered essential in social sciences and human resource management in particular. The statistical software used to evaluate the data was IBM SPSS Statistics 24.

\section{RESULTS AND DISCUSSION}

The Results and Discussion chapter presents the results of the survey implemented in selected agricultural organisations in order to obtain data on the used educational methods and the means of assessing their efficiency.

Tab. I presents the results of the tests of dependency between selected quantitative characteristics, with results ranging from 0.254 (low dependency) to 0.578 (moderate to strong dependency).

Based on the statistical testing, both summary null hypotheses were rejected. Testing has proven a correlation between whether an agricultural organisation develops education systematically, plans educational activities for a pre-defined period and evaluates the efficiency of educational activities and the selected identification variables.

Agricultural organisations that systematically work on education and are planning their educational activities for a pre-defined period are typically large organisations active on the national or international market which have an HR department that's in charge of these activities. On the other hand, small and medium-sized enterprises without an HR department do not take education into consideration at all or limit it only to mandatory trainings. The testing however did not prove any link between systematic planning of education and the sector where the surveyed agricultural organisations are active.

We have determined a relatively strong correlation between systematic evaluations of the efficiency of education and the size of an organisation. As in the previous case, this issue is mainly taken into consideration in large organisations that have an HR department, regardless of their target market. The sector of their activities also plays a relatively significant role, and so does the organisation's involvement in a larger group of organisations. Based on the obtained results, it can be stated that the need to monitor the benefits of education and subsequently adjust the used methods to increase efficiency is mainly felt by state-owned organisations.

From the results above, we can summarise that:

- There is a statistical correlation between whether agricultural organisations are planning and implementing educational activities and selected identification variables characterising the organisation (Cramer's V for individual working hypotheses: 0.254-0.460). The only identification variable that did not show any correlation is the sector of activity.

- There is a statistical correlation between whether agricultural organisations are evaluating the efficiency of education and selected identification variables characterising the organisation (Cramer's V for individual working hypotheses: 0.433-0.578). The only working hypothesis that was accepted (no statistical correlation was proven) concerns the market on which the organisation operates.

To verify the results of the research, the data was also tested using multi-dimensional statistics; specifically a factor analysis working with the identified variables. According to Anderson (2009), the values calculated in the factor analysis indicate the extent to which the newly created

I: Results of dependency tests

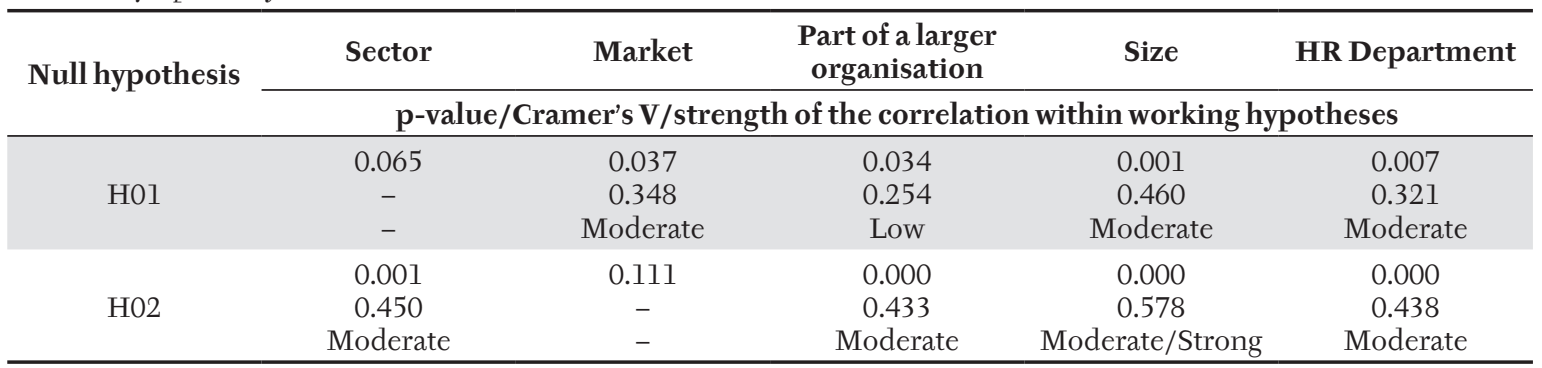

Source: own survey 
variable correlates with the original variables (mutual influence). In other words, it can be stated that the higher the variance of the determined factor, the larger the group of answers (variables entering the analysis) the factor contains and represents based on shared characteristics, similarities and behaviour. The results have identified 4 significant factors that meet the criteria set in line with the methodology. Tab. II shows the significance of individual examined factors describing educational methods applied in agricultural organisations as percentages of the total sum.

The variance of factor 1 can be considered most significant (26.397). In total, the four identified variables explain $63.777 \%$ of the behaviour of the sample or its characteristics. Specific values of the factor analysis are shown in Tab. III.

The first factor shows the importance of a well-chosen combination of educational methods in order to achieve synergies. These agricultural organisations emphasise not only the support of self-education using the internet (0.595-0.775), but realise that personal presence in the educational process is also important (lectures 0.859), and so is partially also obtaining information and experience from agricultural organisations abroad (0.461) which helps see various issues from another perspective. The first factor could be termed "blended learning". The coefficients of the identified factors range between 0.461 and 0.859 , which represents a relatively high quality of the determined coefficients.

With respect to the constant negative development of the age structure of people working in agriculture, the second factor ("knowledge sharing") is also important and may be crucial for those surveyed agricultural organisations that emphasise knowledge and experience sharing. These are typically small family farms that share their tacit intergenerational knowledge through coaching and mentoring (0.825-0.860). We call the third factor a "combination of active and passive learning", emphasising a combination of modern non-interactive methods of education (e-learning, 0.404 ) and gaining experience through job rotation (0.878) and work on projects (0.685). The last factor describes agricultural organisations that focus on strengthening relationships between their employees and therefore often use outdoor learning (0.712) and videoconferences (0.858).

Regarding the second verification of the results concerning the efficiency of the teaching process, we can conclude that the determined spread for factor 1 is very significant (49.088). In total, we have identified two variables that explain $63.505 \%$ of the behaviour of the sample or its characteristics (Tab. IV).

Specific values of the factor analysis are shown in Tab. V.

II: Resultant factors by the Varimax method

\begin{tabular}{cccc}
\hline Factor & Total variance & Total \% of variance & Cumulative \% of variance \\
\hline 1 & 2.904 & 26.397 & 26.397 \\
2 & 1.543 & 14.030 & 40.427 \\
3 & 1.345 & 12.225 & 52.652 \\
4 & 1.224 & 11.125 & 63.777 \\
\hline
\end{tabular}

Source: own survey

III: Resultant factors by the Varimax method, methods of education

\begin{tabular}{lcccc}
\hline \multicolumn{1}{c}{ Variable } & Factor 1 & Factor 2 & Factor 3 & Factor 4 \\
\hline Self-education & $\mathbf{0 . 7 7 5}$ & 0.281 & 0.349 & -0.063 \\
Outdoor learning & -0.025 & 0.181 & 0.344 & $\mathbf{0 . 7 1 2}$ \\
Coaching & 0.048 & $\mathbf{0 . 8 2 5}$ & 0.080 & 0.265 \\
Mentoring & 0.044 & $\mathbf{0 . 8 6 0}$ & -0.082 & -0.037 \\
Internet & $\mathbf{0 . 5 9 5}$ & -0.033 & 0.125 & 0.118 \\
Videoconferences & 0.082 & -0.058 & -0.178 & $\mathbf{0 . 8 5 8}$ \\
E-learning & 0.103 & 0.472 & $\mathbf{0 . 4 0 4}$ & -0.151 \\
Internship abroad & $\mathbf{0 . 4 6 1}$ & -0.089 & -0.155 & -0.239 \\
Job rotation & 0.018 & -0.076 & $\mathbf{0 . 8 7 8}$ & -0.005 \\
Lectures & $\mathbf{0 . 8 5 9}$ & 0.153 & 0.107 & 0.132 \\
Work on projects & 0.289 & 0.132 & $\mathbf{0 . 6 8 5}$ & 0.157 \\
Total \% of Variance & $\mathbf{2 6 . 3 9 7}$ & $\mathbf{4 0 . 4 2 7}$ & $\mathbf{5 2 . 6 5 2}$ & $\begin{array}{c}\mathbf{6 3 . 7 7 7} \\
\text { Name of factor }\end{array}$ \\
Blended learning & Knowledge sharing & $\begin{array}{c}\text { Combination of } \\
\text { learning }\end{array}$ & $\begin{array}{c}\text { Active form of } \\
\text { learning with focus } \\
\text { on relationships }\end{array}$ \\
\hline Soursive
\end{tabular}

Source: own survey 
The first factor emphasises the evaluation of work performance as such; it includes as variables keeping records of the total number of days of education per employee, evaluation of performance in meeting objectives, assessing responses, measuring work performance before and after education and after a period of several weeks or months. These agricultural organisations focus on supporting the efficiency of the educational process and the planning of educational processes. The metrics determined through the evaluation are then used to adjust future educational processes. The first factor can therefore be called "Evaluation of the event". The coefficients of the identified factors range between 0.519 and 0.889 , which represents a relatively high quality of the determined coefficients. The second factor includes 3 values linked to formal feedback from direct managers, including observation at work, and direct feedback from employees. Here the coefficients range from 0.621 to 0.715 . In these agricultural organisations, it can be assumed that they only regularly evaluate work performance in line with long-term procedures which however may be outdated or to a certain degree subjective.

Based on this information, we can agree with Razak et al. (2016) or Lee and Bruvold (2003) that the overall objective of staff education and development is to ensure that all organisations, including those active in agriculture, have the quality of employees they need to achieve their goals. This, however, can only be achieved if the employees have the knowledge and skills necessary to perform their work efficiently and keep constantly improving their skills, maximising their growth potential (Rastgoo, 2016; Lišková and Tomšík, 2013). The results of
Diaz-Fernandez et al. (2017), Barao et al. (2017), Kragulj (2016), Seuneke et al. (2013) and others show that organisations today need to cope with a multitude of external influences and situations that force them to adapt the skills of their employees to the changing conditions in the workplace. Because of the development of new technology and equipment, increasing willingness of the employees to invest in their own education due to the growing competition on the global labour market and other effects of our turbulent times, the most efficient means of employee education in an organisation today is systematic education that is planned, well organised and well targeted (Venkitachalam and Willmott, 2017).

Systematic education also requires selecting the right educational method and the right methodology for evaluating the results of the educational process. Nevertheless, Robbins et al. (2003) point out that many employers are against educational and development activities in the workplace, because they believe that professional training is the responsibility of school institutions or the employees themselves; Hitka et al. (2015) add that another strong factor is self-motivation. The results of this survey, however, indicate a positive approach to employee education among Czech agricultural organisations, as well as a trend to support the educational process through a suitable selection of educational methods and feedback assessment. Based on a summary of the results of research implemented in the Czech Republic and elsewhere (e.g. Liu (2017); Razak et al. (2016); Lišková, Tomšík (2013), Seuneke et al. (2013), it can be stated that organisations in general support employee education and development,

IV: Resultant factors by the Varimax method

\begin{tabular}{cccc}
\hline Factor & Total variance & Total \% of variance & Cumulative \% of variance \\
\hline 1 & 3.927 & 49.088 & 49.088 \\
2 & 1.153 & 14.418 & 63.505 \\
\hline
\end{tabular}

Source: own survey

V: Resultant factors by the Varimax method, efficiency of the educational process

\begin{tabular}{lcc}
\hline Variable & Factor $\mathbf{1}$ & Factor $\mathbf{2}$ \\
\hline Keeping records of the total number of days of education per employee & $\mathbf{0 . 5 7 8}$ & 0.194 \\
Evaluation of performance in meeting objectives & $\mathbf{0 . 7 5 3}$ & 0.265 \\
Assessing responses of the employees after the education & $\mathbf{0 . 5 1 9}$ & 0.507 \\
Measuring work performance before and after education & $\mathbf{0 . 8 8 9}$ & $\mathbf{0 . 0 9 8}$ \\
Measuring work performance after education but after a period of & $\mathbf{0 . 7 1 9}$ & 0.332 \\
several weeks or months & 0.359 & $\mathbf{0 . 7 1 5}$ \\
Formal feedback from direct managers & 0.608 & $\mathbf{0 . 6 2 1}$ \\
Formal feedback from employees & -0.053 & $\mathbf{0 . 8 4 9}$ \\
Observation at work & $\mathbf{4 9 . 0 8 8}$ & $\mathbf{6 3 . 5 0 5}$ \\
Total \% of Variance & $\mathbf{E v a l u a t i o n ~ o f ~ t h e ~}$ & event \\
Name of factor & Passive evaluation \\
\hline
\end{tabular}

Source: own survey 
even though this takes a significant amount of time. The initiative promoting professional and personal development, however, shouldn't be coming just from the organisation, but also from the employees themselves. The competitive advantage of a knowledgeable employee drops over time due to the half-life of information and skills, as confirmed by the research of Urbancová and Čermáková (2015). It is important for employees to realise that education is essential, to get motivated, to want to be involved in the education and training process and to actively look for new ways to grow.

In summary, if the management of an organisation creates the right conditions for its employees and if the process of education and development is well managed, the results show a synergy effect. Unfortunately, the conditions for employees in education and development vary greatly among individual agricultural organisations.

\section{CONCLUSION}

Today, when the most valuable resource of any organisation, including in agriculture, are qualified employees, it's increasingly more important for small organisations to focus on continuous education of their employees. Only by implementing this HR activity, which is an essential pillar of human resources management, can an enterprise achieve long-term success. Agricultural organisations, like many others, are currently facing a lack of qualified workforce, which is why it is necessary not only to systematically educate current staff, but also to improve on-boarding programs for new recruits. The results show that most of the surveyed agricultural organisations have implemented an educational process in order to develop the competencies of their staff. There are however clear differences in the use of individual educational methods and the methodology of evaluating the efficiency of the educational process. Factor analysis was used to identify 4 groups of agricultural organisations based on their approach to the application of educational methods: these are organisations who prefer "blended learning", "knowledge sharing", a "combination of active and passive learning" and an "active form of learning with focus on relationships" (0.404-0.878). After the educational activity itself, the surveyed agricultural organisations prefer to either "evaluate the event" (factor 1), which are primarily organisations that have an HR strategy, or perform "passive evaluation" (factor 2) if they do not.

The presented results have verified the theoretical assumptions concerning the use of individual educational methods and the methodologies for assessing efficiency of the educational process used in the specific field of agriculture. Future research could focus on analysing the differences between the use of educational methods among various categories of staff-graduates (of agricultural and other fields), experienced employees and senior staff.

\section{Acknowledgement}

This article was supported by the Internal Grant Agency of the University of Life Sciences Prague (CIGA) [No. 20171001], "Assessing the quality of instruction in the selected field at the Faculty of Economics and Management of the Czech University of Life Sciences Prague".

\section{REFERENCES}

ANDERSON, V. 2009. Research Method in Human Resource Management. $2^{\text {nd }}$ Edition. London: Chartered Institute of Personnel Development.

ARAÚJO, J. and PESTANA, G. 2017. A framework for social well-being and skills management at the workplace. International Journal of Information Management, 37(6): 718-725.

ASWATHAPPA, K. 2005. Human resource and personnel management: text and cases. $4^{\text {th }}$ Edition. New Delhi: Tata McGraw-Hill.

BARAO, A., DE VASCONCELOS, J. B., ROCHA, Á. and PEREIRA, R. 2017. A knowledge management approach to capture organizational learning networks. International Journal of Information Management, 37(6): $735-740$.

DÁVIDEKOVÁ, M., MJARTAN, M. and GREGUŠ, M. 2017. Utilization of Virtual Reality in Education of Employees in Slovakia. Procedia Computer Science, 113: 253-260.

DE VAUS, D. 2014. Surveys in social research. $6^{\text {th }}$ Edition. Abingdon, Oxon: Routledge, Studies in Society.

DIAZ-FERNANDEZ, M., PASAMAR-REYES, S. and VALLE-CABRERA, R. 2017. Human capital and human resource management to achieve ambidextrous learning: A structural perspective. BRQ Business Research Quarterly, 20(1):63-77.

HANAYSHA, J. and TAHIR, P. R. 2016. Examining the Effects of Employee Empowerment, Teamwork, and Employee Training on Job Satisfaction. Procedia - Social and Behavioral Sciences, 219: 272-282.

HEBÂK, P. et al. 2014. Statistické myšlení a nástroje analýzy dat. Praha: Informátorium.

HENDL, J. 2012. Přehled statistických metod: analýza a metaanalýza dat. $4^{\text {th }}$ Edition. Praha: Portál. 
HITKA, M., STACHOVÁ, K., BALÁŽOVÁ, Ž. and STACHO, Z. 2015. Differences in Employee Motivation at Slovak Primary Schools in Rural and Urban Areas. International Education Studies, 8(5): 33-42.

KRAGULJ,F.2016. Conceptualising Needs to Enhance OrganisationalLearning andEnableKnowledge-Based Innovation. Procedia Computer Science, 99(C): 225-242.

LEE, C. H. and BRUVOLD, N. T. 2003. Creating Value for Employees: Investment in Employee Development. International Journal of Human Resource Management, 14(6): 981-1000.

LIU, C. H. 2017. Creating competitive advantage: Linking perspectives of organization learning, innovation behavior and intellectual capital. International Journal of Hospitality Management, 66: 13-23.

LIŠKOVÁ, S. and TOMŠÍK, P. 2013. Competency-based approach to human resources management. Agriculture Economics, 59(11): 496-504.

PECÁKOVÁ, I. 2011. Statistika v terénních průzkumech. Praha: Professional Publishing.

PULAKOS, E. D., HANSON, R. M., ARAD, S. and MOYE, N. 2015. Performance Management Can Be Fixed: An On-the-Job Experiential Learning Approach for Complex Behavior Change. Industrial and Organizational Psychology, 8(1): 51-76.

RAO, D. S. and KUMAR, P. V. 2017a. Evaluation of Training Effectiveness Based on Behaviour. International Journal of Human Resources Management, 6(4):

RAO, D. S. and KUMAR, P. V. 2017b. Evaluation of Training Effectiveness Based on Reaction - A Case Study. International Journal of Business and General Management, 6(4): 45-56.

RASTGOO, P. 2016. The Role of Human Resources Competency in Improving the Manager Performance. Acta Universitatis Agriculturae et Silviculturae Mendelianae Brunensis, 64(1): 341-350.

RAZAK, N. A., PANGIL, F., MDZIN, M.L., YUNUS, N.A. M. and ASNAWI, N. H. 2016. Theories of Knowledge Sharing Behavior in Business Strategy. Procedia Economics and Finance, 37: 545-553.

ROBBINS, S. P., ODENDAAL, A. and ROODT, G. 2003. Organizational behavior: Global and Southern African perspectives. Pearson Education, South Africa.

SAKS, A. M. and HACCOUN, R. 2010. Managing performance through training and development. $5^{\text {th }}$ Edition. Toronto: Nelson Education.

SEUNEKE, P., LANS, T. and WISKERKE, J. S. C. 2013. Moving beyond entrepreneurial skills: Key factors driving entrepreneurial learning in multifunctional agriculture. Journal of Rural Studies, 32: 208-219.

ŠÜMANE, S., KUNDA, I., KNICKEL, K., et al. 2017. Local and farmers) knowledge matters! How integrating informal and formal knowledge enhances sustainable and resilient agriculture. Journal of Rural Studies, 59: 232-241.

URBANCOVÁ, H. and ČERMÁKOVÁ, H. 2015. The costs of Age Management in agricultural companies. Agricultural Economics, 61(1): 14-22.

VENKITACHALAM, K. and WILLMOTT, H. 2017. Strategic knowledge management - Insights and pitfalls. International Journal of Information Management, 37(4): 313-316.

VODÁK, J. and KUCHARČÍKOVÁ, A. 2011. Efektivní vzdẻlávání zaměstnanců. $2^{\text {nd }}$ Edition, Praha: Grada, Management.

Hana Urbancová: urbancova@pef.czu.cz Adéla Fajčíková: fajcikova@pef.czu.cz Václav Kala:kala@pef.czu.cz 